\title{
Word Formation Processes in the Oprah Winfrey's Talkshow with J.K Rowlling: Article FBS UNIMA
}

\author{
${ }^{1}$ Lisa A. Wuri, ${ }^{2}$ Deane J Wowor, ${ }^{3}$ Sarah Kamagi \\ ${ }^{1}$ Universitas Negeri Manado, Manado, North Sulawesi \\ English Education Department
}

\begin{abstract}
This study aims at identifying and describing the process of Word Formation in The Oprah Winfrey talkshow. This is qualitative research since the data were collected in the form of word not in number. The data is collected through by taking notes then underlining the data concerning word formation from the talkshow's transcript. The instrument of this research were, researcher herself, and the talkshow transcript. The data were analyzed by following the steps of Miles and Huberman (1994:10-11) procedur such as data reduction, data display and conclusion drawing/verivication. The result shows that the process of word formation in The Oprah Winfrey's talkshow contained derivation and compounding. The example of derivation are the words reader, producer, and homeless, and the example of compounding such as standout, moreover, and outside. The derivation process is mostly used rather than the compounding. It is suggested to the coming researcher to do the analysis of word formation process in another types of word formation.
\end{abstract}

Keywords: Word Formation, The Oprah Winfrey Talkshow, Derivation, Compounding.

\section{INTRODUCTION}

Language is very important in our daily life it is used as an instrument to communicate with each other. With language we can understand what others actually mean. Also, with language, we can share information, ideas, opinions, and express our feelings "Without language people would find problems in sharing information, interacting with others, showing sympathies and clarifying important cases" (Liando, N.V.F and Lumettu, R. 2017 page 21). Based on Maru, Mister Gidion; Ratu, Donal Matheos; Dukut, Ekawati Marhaenny (IJET Vol 7, No 3.25 (2018), 386-390) : the mastery of language expressions deter-mines the share thinking, the critical thinking process gives the value for the language expression.Kamagi and Wowor (2018:847) stated language constitutes a means of communication. Language is formed from sentences and words. Word is formed by a morphological process.

Morphology is the study of word structure and how it formed. In linguistics morphology refers to the mental system involved in word formation or to the branch of linguistics that deals with words, they internal structure and how they are formed ( M. Aronoff \& K. Fudeman, 2011:2 ). Morphology as a part of linguistics, that explain more about 
word structure and rules by which the words are formed. In morphology, we can find the process of word formation, and how the smallest meaningful units of language called morpheme form a word .

Word formation is defined as the way in which new word are form. The study of word formation can be defined as the study of the ways in which new complex words are built on the basis of other words or morphemes ( Plag, 2003 : 17) . There are a few types of $w$ ord formation. According to O'Grady et al., (1997: 144 - 160) in morphology there are ten word formation processes. There are derivation, compounding, conversasion, clipping, blends, backformation, acronyms, onomatopoeia, coinage, and inflection.

The use of language can be found in various media, such as audio, visual and visual media. Television is one of the audio visual media, that shows information program, like the news, documentaries, TV series, and talk show. A talk show is a television program or radio program where guest star discusses various topics with a talk show host.

Oprah Winfrey's talk show is one of the very famous talk show in the world and has many positive responses. It is an American syndicated talk show that ran nationally for 25 season from 1986 to 2011, produced and hosted by Oprah Winfrey. It remains the highest rated talk show in American television history.

Based on the description above, it is interesting for the researcher to analyze the use of word formation, how that word formation process and also the researcher want to classify the types of word formation that found in Oprah Winfrey's talk show.

\section{RESEARCH METHOD}

- Method of research

In this research, the researcher used qualitative. Because the researcher describes phenomena in words instead of numbers or measurement. According to Cresswell (1994:145) "Qualitative research is descriptive in that the researcher is interested in process, meaning and understanding gained through word or picture."

- Data Collection

In this research, the data were collected from the transcript of The Oprah Winfrey's Talk Show with J.K Rowlling. The data consisted of the words that contain of word formation that found in The Oprah Winfrey's Talk Show with J.K Rowlling. The instrument of this research is the writer herself.

- Data Analysis

The researcher analyzed and identified the word formation process that found in The Oprah Winfrey's Talk Show with J.K Rowlling. In this study, the researcher used the theory of Miles and Huberman (1994:10-11) which is involving three steps: data reduction, data display, and conclusion drawing/verivication.

a) Data Reduction :

In this step, all the data were collected through reading the transcript of The Oprah Winfrey's talkshow with J.K Rowlling, then underlining the words that contain word formation in derivation and compounding, then transcribed the data by only focusing to the data that related 
to the research. After collecting and reducing the data, the researcher displayed those data in the form of descriptive.

b) Data Display

In this step, the data displaying based on the formulation of . research question. The researcher shows or display the data, by divided the data into the types of word formation, then describing the process of word formed that found in the data

c) Conclusion Drawing :

In this step, after finished doing data reduction and data display, the researcher discuss about what the data mean and to assess their implications for the questions.

\section{DATA ANALYSIS}

In this chapter the researcher would like to analyze the word formation processes in The Oprah Winfrey's talkshow with J.K Rowlling

a) Data Reduction

1. Oprah Winfrey : J.K Rowlling sell more than four hundred million books, captivate readers, in sixty-nine languages. ( Utterance number 1)

2. Oprah Winfrey 16.

Rowlling is the first self-made billionaire in author History. ( Utterance number 1)

3. Oprah Winfrey : The J.K Rowlling legend begins with a delightful children's book. ( Utterance number 1)

4. Oprah Winfrey : Her empire spans movies and mek\&handise (Utterance number 1)
5. J.K Rowlling : And my producer told me that your real name is Jo ( Utterance number 4)

6. J.K Rowlling : Is just the nom de - well, it's because my British publisher, (Utterance number 7)

7. J.K Rowlling : So I took my grandmother's name Kathleen. ( Utterance number 7)

8. Oprah Winfrey : Yes, and I don't think the boys have minded. (Utterance number 16)

9. J.K Rowlling: there came a day where the window cleaner came. (Utterance number 22)

10.J.K Rowlling : and I think writers can be a little bit superstitious. (Utterance number 22)

11.J.K Rowlling : a children's book, moreover that I'd been told repeatedly that wasn't very commercial (Utterance number 42)

12. J.K Rowlling : That's a real standout moment for me (Utterance number 50)

13. J.K Rowlling : I was barely hanging by a thread. (Utterance number 50)

14. Oprah Winfrey : Here among the cobblestone streets and quaint cafes J.K., then a stuggling single mother (Utterance number 51)

15. J.K Rowlling: Well, the screenwriter (Utterance number 55)

Oprah Winfrey : What about all the criticism that you received from a lot of religious people who felt that it was too dark and frightening (Utterance number 82)

J.K Rowlling : You must not discuss witchcraft, you must not have witches or magic depicted in a book (Utterance number 87)

J.K Rowlling : It was literally as poor as you can get in Britain without being homeless (Utterance number 106) 
J.K Rowlling : I feel enlightened in any way (Utterance number 163)

J.K Rowlling : Integrity was very important and kindness and a very strong sense of who he was (Utterance number 167)

- List of words that contain Word Formation Processes

1. Reader

2. Billionaire

3. Delightful

4. Merchandise

5. Producer

6. Publisher

7. Grandmother

8. Minded

9. Cleaner

10. Superstitious

11. Moreover

12. Standout

13. Barely

14. Cobblestone

15. Screenwriter

16. Frightening

17. Witchcraft

18. Homeless

19. Enlightened

20. Kindness

b) Data Display

In this section, the researcher would like to displaying the data based on the research questions: what types and what are the processes of word formed found in The Oprah Winfrey's talk show with J.K Rowlling. The collected data are in a form of analysis of word formation and describing the process of each word. The detailed is here as follows.

\section{Process of Word Formation}

\section{Reader}

$\operatorname{Read}(\mathrm{V})+\mathrm{er} \rightarrow \operatorname{Reader}(\mathrm{N})$

The suffix 'er' change the meaning or the word class. It forms a new word with meaning 'a person who does the action of the noun'. The word reader classified as derivational process.

\section{Delightful}

Delight(V) + ful $\rightarrow$ Delightful(Adj)

The word delight is a base and 'ful' is a suffix. When the suffix added to the base word, a new word delightful is forms with meaning 'very pleasant'. The word delightful classified as derivational process

\section{Billionaire}

Billion $(\mathrm{N})+$ aire $\rightarrow$ Billionaire $(\mathrm{N})$

The suffix 'aire', when it attach to the base word billion. It forms a noun with meaning ' an extreamly rich person'. The word billionaire classified as derivational process.

\section{Merchandise}

$\operatorname{Merchant}(\mathrm{N})+$ ise $\rightarrow$ Merchandise $(\mathrm{N})$

The suffix 'ise' change the meaning when it attach to the base word merchant. It forms a new word with meaning 'goods that are bought or sold'. The word merchandise classified as derivational process.

\section{Producer}

Produce $(V)+$ er $\rightarrow$ Producer $(\mathrm{N})$ 
The suffix 'er' change the meaning or the word class, when it attach to the the base word produce, it forms a noun with meaning 'a person or company who produce or make something' . The word producer classified as derivational process.

\section{Grandmother}

Grandmother is made from the words grand (Adj) and mother (N) . Grand means 'something that impressive or important' and means 'a female parent'.The word grandmother joined together and form a new meaning as 'the mother of our father or mother'.This categorized as compounding process

\section{Publisher}

$$
\text { Publish(V) }+ \text { er } \rightarrow \text { Publisher(N) }
$$

The suffix 'er' change the meaning or the word class, when it attach to the the base word publish. It forms a new word with meaning 'a person or company that does the action of verb'. The word publisher classified as derivational process.

\section{Minded}

$$
\operatorname{Mind}(\mathrm{N})+\text { ed } \rightarrow \operatorname{Minded}(\operatorname{Adj})
$$

The word minded is created where the meaning or the word class is different from the base word mind, by adding suffix 'ed'. It forms an adjective with meaning 'having the way of thinking, the attitude or the type of character mentioned'. The word minded classified as derivational process.

\section{Cleaner}

$$
\text { Clean(Adj) }+ \text { er } \rightarrow \text { Cleaner(N) }
$$

The suffix 'er' change the meaning or the word class, when it attach to the the base word clean . It forms a noun with meaning 'a person whose job is to clean something'. The word cleaner classified as derivational process.

\section{Superstitious}

Superstitious is made from the words $\operatorname{super}(\mathrm{N})$ and stitious(Adj) . Super means 'extremely good' and stitious means 'feel awkward'. The word superstitious is from two different words that joined together to forms a new word as 'believing in myth'. This categorized as compounding process

\section{Barely}

Bare(Adj) + ly $\rightarrow$ Barely(Adv)

The suffix 'ly' change the meaning of the base word bare, when it attach to it. It forms a new word with meaning 'in a way that almost does not happen or exist'. The word barely classified as derivational process.

\section{Moreover}

The word Moreover is a compound word, from the words more(Adv) and over(Adv). More means 'a larger number or amount of' and over means 'from one side to another side, when it joined together it became a new word as 'used to introduce some new information'. The process called compounding.

\section{Standout}

Standout categorized as a compounding because it is a combine of two words $\operatorname{stand}(\mathrm{V})$ and out(Adv) . Stand means 'o be in a vertical position' and out means 'away from the inside of a place or thing'. These two words combined, and it became a new word with meaning 'very noticeable because of being better'. This process categorize as compounding

\section{Cobblestone}


Cobblestone is a combine of two words, cobble $(\mathrm{N})$ and stone $(\mathrm{N})$. Cobble means 'round rock' and stone also means as 'rock'. These two words joined together and forms a new word 'stone with curved top; once used to make roads' . The process called compounding.

\section{Screenwriter}

Screenwriter is made from screen $(\mathrm{N})$ and writer $(\mathrm{N})$.

Screen means 'the large flat surface that films/movies or pictures are shown on' and writer means 'a person whose job is writing books, stories, articles, etc'. The word screenwriter is from two different words that joined together to forms a new word 'a person who writes screenplays'.This process categorized as compounding.

\section{Frightening}

Frighten(V) + ing $\rightarrow$ Frightening(Adj)

The suffix 'ing' change the meaning or the word class, when it attach to the the base word frighten .It forms an adjective with a meaning 'make us feel afraid' The word frightening classified as derivational process

\section{Homeless}

Home $(\mathrm{N})+$ less $\rightarrow$ Homeless(Adj)

The suffix 'less' change the meaning and the word class, when it attach to the base word 'home' . It forms an adjective with meaning 'having no home'. The word homeless classified as derivational process.

\section{Enlightened}

$$
\text { Enlighten(V) }+ \text { ed } \rightarrow \text { Enlightened(Adj) }
$$

The word enlightened is created where the meaning or word class is different from the base word enlighten, by adding suffix 'ed'. It forms an adjective with meaning having or showing an understanding of people's needs, a situation, etc'. The word enlightened classified as derivational process.

\section{Kindness}

$\operatorname{Kind}(\operatorname{Adj})+$ ness $\rightarrow$ Kindness $(\mathrm{N})$

The suffix 'ness' change the meaning and the word class, when it attach to the base word 'kind'. It forms a noun with meaning 'the quality of being kind'. The word kindness' classified as derivational process.

\section{Typewriter}

Typewriter is a combine from two words type $(\mathrm{V})$ and writer $(\mathrm{N})$. Type means 'a kind or sort' and writer means 'a person whose job is writing books, stories, articles, etc'. Then, this two words joined together and became a new word means 'machine that produces writing similar to print'. This process categorized as compounding

\section{CONCLUSION}

From the findings above, it was found that the most frequent used of type of word formation in the The Oprah Winfrey's talk show with J.K rowlling was derivation. In this reaserch, it was also found that some of the derivation process do not change the word class and only change the meaning of the base word. For example is the word Impossible (Im + possible(Adj) $\rightarrow$ Impossible(Adj)), when the prefix Im applies to the base word, it change the meaning but not the word class. The researcher also found the compounding process. Compounding consist in 
combination of two words to form a new word.

In this research, the researcher found 11 data.

For example moreover, standout, and screenwriter. This two types of word formation, change the meaning of the words, in the process to forming a new word.

\section{BIBLIOGRAPHY}

Aronff, Mark and Fudeman K. 2011. What is Morphology. United Kingdom: Blackwell Publishing Ltd.

Creswell, John W. 1994. Research Design: Qualitative, Quantitative, and Mixed Methods Approaches. United States of America: Sage Publication, Inc.

Fromkin, et al. 2014. An Introduction to Language. South Melbourne: Cengage Learning Australia.

Hockett, F, Charles. 1958. A Course In Modern Linguistics. New York: Prentice Hall Colage

Kamagi, Sarah and Wowor Deane. 2018. A Study on Verbal Phrases in Tagulandang Dialect of Sangirese, 226, 847. sarahkamagi@unima.ac.id, deanewowor@unima.ac.id

Liando, N.V.F and Lumettu, R. 2017. Student's Personal Initiative Towards their Speaking Performance. International Education Studies, vol.5, no. 6 ; 2017.

Maru, Mister Gidion; Ratu, Donal Matheos; Dukut, Ekawati Marhaenny (2018). The Use of the T-Ex Approach in Indonesian EFL Essay Writing: Feedbacks and Knowledge Exploration. IJET Vol 7, No 3.25 (2018), page 386-390.

Miles, B, Matthew and Huberman, M, A. 1994. Qualitative Data Analysis. California: SAGE Publications, Inc.

Tahaineh, Y and Jordan. 2012. The Awareness of the English Word-formation Mechanisms is a Necessity to Make an Autonomous L2 Learner in EFL Context. Journal of Language Teaching and Research, 3 (6): 1107
Yule, George 1985. The Study of Language ( $1^{\text {st }}$ edition). Cambridge: Cambridge University Press.

Yule, George. 2010. The Study of Language (4 ${ }^{\text {th }}$ edition). United States of America: Cambridge University Press 